\title{
熱分解-ガスクロマトグラフィーによるポリエステルの 組成分析における誘導体化法の検討
}

\author{
佐 藤 貞 幸* \\ (1991 年 9 月 21 日受理)
}

\begin{abstract}
Challinorにより提唱された，熱分解-誘導体化一ガスクロマトグラフィーを $p$-ヒドロキシ安息香酸よ 2-ヒドロキシ-6-ナフトエ酸から成るコポリエステルの組成分析に適用した。しかし，そのパイログラム 上には未誘導体化物であるフェノールが検出され，誘導体化が十分起こっていないことが明らかとなっ た。そこで, 著者はより高い誘導体化率を得るために, 誘導体化条件の最適化検討を行い, 最終的に, 誘導体化試薬をマイクロシリンジで直接熱分解装置内に導く直接導入法を開発し, 上述のポリエステル の主なフラグメントであるフェノールを 95 モル％以上の誘導体化率でメトキシベンゼンに誘導体化 できた。更に，本法を幾つかのポリマーの組成分析に適用し，十分な誘導体化率が得られることを明ら かにした。
\end{abstract}

\section{1 緒言}

熱分解ガスクロマトグラフィー (pyrolysis-gas chromatography, Py-GC) は, ポリマーの組成分析に有効な 手法であり，特にキャピラリーカラムを装着した高分解 能 Py-GC 法は, 従来の充てんカラムを使用した Py-GC と比較して, ポリマーの構造に関して, より有 効な知罗を与えるり.

しかし, 高分解能 $\mathrm{Py}-\mathrm{GC}$ といえども, 熱分解により 高極性化合物，すなわちフェノール化合物やカルボン酸 化合物を生成するポリマーの分析にはあまり有効とはい えない，これは，GC そのものが，この種の高極性化合 物の分析に不向きであることによるものであり，通常の $\mathrm{GC}$ 分析では高極性化合物の分析のために, メチル誘導

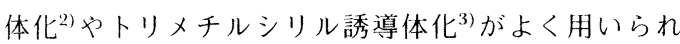
る.しかし, Py-GG では, 熱分解生成物は即坐に直接 カラムに導かれるため, 誘導体化試薬の導入が難しく, 通常の誘導体化法は適用できない.

近年, Challinorにより, Py-GCにおいて, 効果的な 誘導体化試薬の添加法が開発され，各種のポリマーの組 成分析に適用された ${ }^{4)}$.この手法では誘導体化試薬は試 料と共に熱分解され, 同時に分解生成物の誘導体化が行 われる。

著者は，この手法を $p$-ヒドロキシ安息香酸と 2-ヒド

* 出光石油化学(株)樹脂研究所：299-01 千葉県市原市 姉崎海岸 1-1
ロキシ-6-ナフトエ酸から合成されるコポリエステルの 組成分析に適用した。従来の Py-GCにより得られる主 な熱分解生成物は, ベンゼン, フェノール, ナフタレ ン，2-ナフトールなどであり，それらの情報のみからこ のポリエステルの構造を推定することは困難であった. それに対して, 熱分解-誘導体化-ガスクロマトグラフ イーでは, メトキシベンゼン, メトキシナフタレン, 安 息香酸メチルの他に $p$-メトキシ安息香酸メチルや2-メ トキシ-6-ナフトエ酸メチルも検出され, それらのフラ グメントは值接このコポリエステルのコモノマー構造に 対応する.このことより，本手法がこの種のポリマーの 組成分析のために有効であることが分かる.

しかし, Challinor の方法で得られたパイログラム上 には，上述の化合物の他に未反応のフェノールも検出で き，本条件下では十分な誘導体化が起こっていないこと が分かった。そこで, 著者はより高い誘導体化率を得る ために，誘導体化条件の最適化検討を行った。この報文 では，本検討より開発されたより高い誘導体化率が得ら れる手法を提案すると共に, 誘導体化の機構について若 干の考察を行う.

\section{2 実験}

\section{$2 \cdot 1$ 装}

熱分解は, キューリーポイントパイロライザー（日本 分析工業製 JHP-3 型) をガスクロマトグラフ（日立製 作所製 G-3000 型) に接続して行った。 カラムは，溶融 
シリカキャピラリーカラム (GL サイエンス製 DB-1701 $1.5 \mu \mathrm{m} \times 0.25 \mathrm{~mm}$ i.d. $\times 50 \mathrm{~m})$ を用いた。注人 モードは，スプリット法を用いスプリット比を 1:50 とした. 温度プログラムは, 初期温度 $40^{\circ} \mathrm{C}$ で 5 分間 ホールドした後, $5^{\circ} \mathrm{C} / \mathrm{min}$ の昇温速度で $280^{\circ} \mathrm{C}$ まで昇 温した。

熱分解は, 分解温度 $764^{\circ} \mathrm{C}$, 分解時間 5 秒で行った.

すべての, 熱分解生成物はガスクロマトグラフに結合 した質量分析計（日本電子製 JEOL モデル JMS-AX505H）で同定した.MS の測定条件は，イオ ン化エネルギー $70 \mathrm{eV}$, エミッター電流 $300 \mu \mathrm{A}$ とし た.

\section{$2 \cdot 2$ 実験方法}

試料（約 $0.1 \mathrm{mg}$ ）を, $764^{\circ} \mathrm{C}$ のパイロホイルに包み 込み Fig. 1 に示す熱分解用プローブにセットした。 誘 導体化試薬は, そのプローブに装着されたセプタムよ り, 所定のタイミングでマイクロシリンジを用いて直接 熱分解炉内に導入した。誘導体化試薬として, 水酸化テ トラメチルアンモニウム $\left\{\left(\mathrm{CH}_{3}\right)_{4} \mathrm{NOH}\right\} 25 \% \mathrm{w} / \mathrm{w}$ 水 溶液を用い, その導入量は $3 \mu \mathrm{l}$ とした。

\section{$2 \cdot 3$ 試 料}

$p$-ヒドロキシ安息香酸と 2-ヒドロキシ-6-ナフトエ酸 から合成されるコポリエステルは，ポリプラスチック製 Vectra-A-950 を用いた。 その他, 市販のビスフェノー

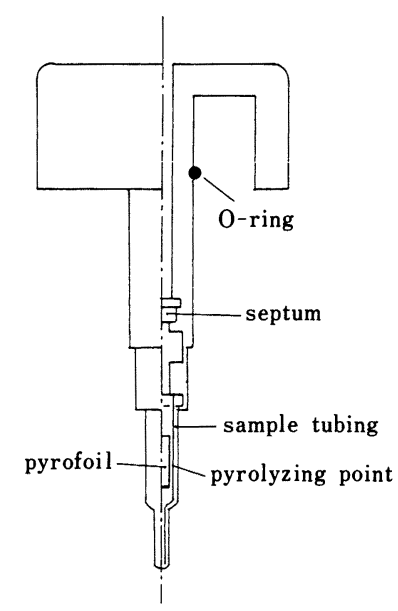

Fig. 1 Diagram of the probe of the Curie-point pyrolyzer used for the direct injection method Alkylating reagent was injected through the septum into the pyrolyzing point.
ル-A 型ポリカーボネート, ポリフェニレンスルフィ ド, テレフタル酸, イソフタル酸, ビスフェノール-A から成るポリアリレートを用いた。

\section{$\mathbf{2 \bullet 4}$ 試 薬}

誘導体化試薬である, 水酸化テトラメチルアンモニウ ム $25 \% \mathrm{w} / \mathrm{w}$ 水溶液は, Aldrich Chemical 製を用いた。

\section{3 結果亡考察}

\section{3・1 Challinor 法のトレース}

まず, 試料に誘導体化試薬を添加した後, 熱分解装置 内に導入する Challinor の手法による熱分解-誘導体化ガスクロマトグラフィーを $p$-ヒドロキシ安息香酸と 2ヒドロギシ-6-ナフトエ酸から合成されるコポリエステ ルの組成分析にそのまま適用した．分析条件で Challinor 法と異なる点は，1）Challinor 法では試料量が $5 \mu \mathrm{g}$ であるのに対しここでは $0.1 \mathrm{mg}$ である.2) Challinor 法では誘導体化試薬として水酸化テトラメチルアン モニウム $40 \% \mathrm{w} / \mathrm{w}$ 水溶液を用いるているのに対し,こ

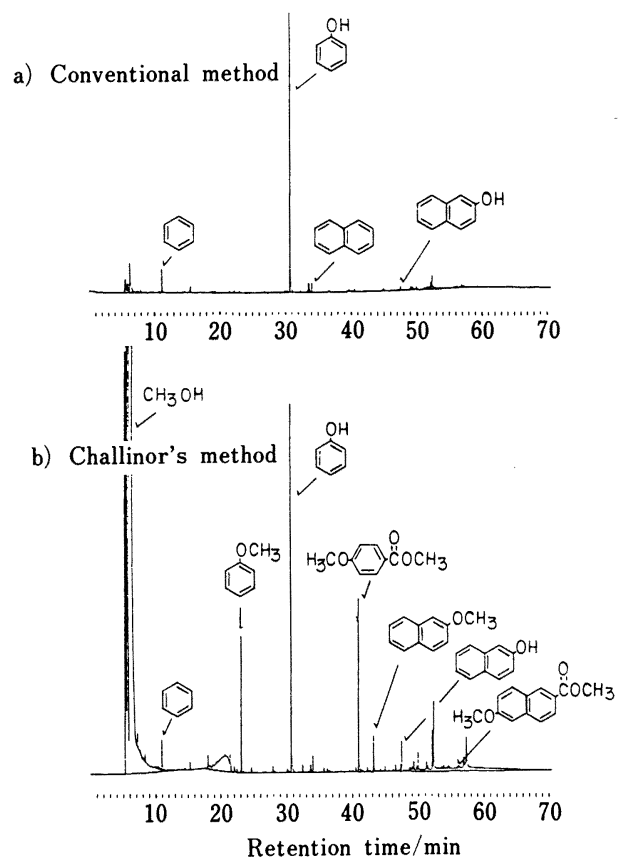

Fig. 2 Pyrograms of copolyester observed by a) conventional method (sample weight: ca. $0.1 \mathrm{mg}$ ) and b) Challinor's method (sample weight: ca. 0.1 $\mathrm{mg}$ )

Copolyester: $25 \% \mathrm{w} / \mathrm{w}$ tetramethylammonium hydroxide aqueous solution $(3 \mu \mathrm{l})$ 
こでは $25 \% \mathrm{w} / \mathrm{w}$ 水溶液を用いた.

Fig. 2 にコポリエステルの通常のパイログラムと, Challinor 法によるパイログラムを示した. 通常の Py-GCにより得られる主な熱分解生成物は, ベンゼ ン, フェノール, ナフタレン，2-ナフトールなどであ り，それらの情報のみからこのポリエステルの構造を推 定することは困難である。それに対して，Challinor 法 では, メトキシベンゼン, メトキシナフタレン, 安息香 酸メチルの他に, 直接このコポリエステルのモノマー構 造に対応する $p$-メトキシ安息香酸メチルや 2 -メトキシ. 6-ナフトエ酸メチルも検出され，このことは，本手法が この種のポリマーの組成分析に有効であることを示して いる.

しかし，得られたパイログラム上には，上述の化合物 の他に未反応のフェノールも検出され，本条件下では十 分な誘導体化が起こっていないことが分かった。 そこ で，著者はより高い誘導体化率を得るために，誘導体化 条件の最適化検討を行った.

\section{$3 \cdot 2$ 誘導体化試薬量の検討}

著者は, 試料量に対する誘導体化試薬量を増加させる ことにより，高い誘導体化率が得られると考え，誘導体 化試薬量と誘導体化率との関係を検討した。しかし，誘 導体化試薬は液体であり，パイロホイルに包み得る量に は限界があるため, 実際には誘導体化試薬量一定で, 試 料量を減少させることにより, 誘導体化試薬量/試料量 比を増加させた。

試料量に対する誘導化試薬量のモル比は, 式( 1 )のよ

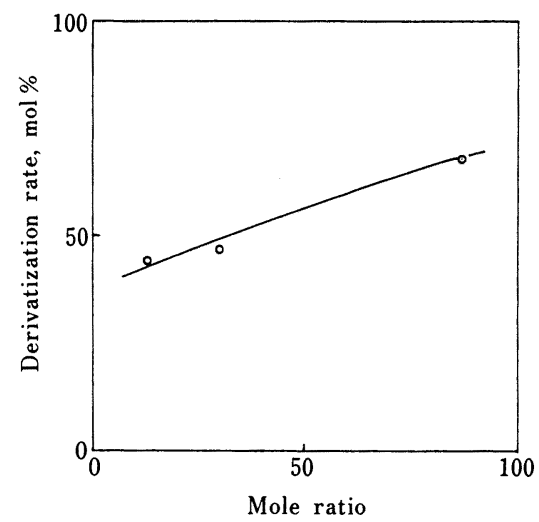

Fig. 3 Relationship between the ratio of alkylating reagent to sample and derivatization rate in Challinor's method

The mole ratio was varied by varying the sample weight at the constant reagent volume $(3 \mu \mathrm{l})$.
うに定義した.

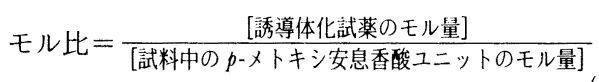

誘導体化率は, 式( 2 )のように定義した.

[誘導体化率 (モル\%)]

$$
\begin{aligned}
= & \frac{[\text { メトキシベンゼンのモル量 }]}{[\text { ×トキシベンゼンのモル量 }]+[\text { フエノールのモル量 }]} \\
& \times 100
\end{aligned}
$$

Fig. 3 にモル比と誘導体化率の関係を示した。それよ り, モル比の増加に伴い, 誘導体化率が増加しているの が分かる.

試料量 $18 \mu \mathrm{g}$, 誘導体化試薬量 $3 \mu \mathrm{l}$, モル比で約 87 の 時, 最大 70 モル％の誘導体化率が得られたが，まだ 満足できる誘導体化率ではない，しかしこれ以上，試料 量を減少させることは, FID の感度から適当ではない と考えられる.

\section{$3 \cdot 3$ 直接導入法}

本反応系においては, 最初に熱分解が起こり, 次いで 誘導体化反応が起こっていると考えられる. よって，高 い誘導体化率を得るためには，完全に熱分解が終了する まで, 誘導体化試薬は系内に存在しなければならない. しかし，実際には誘導体化試薬はポリマーが完全に熱分

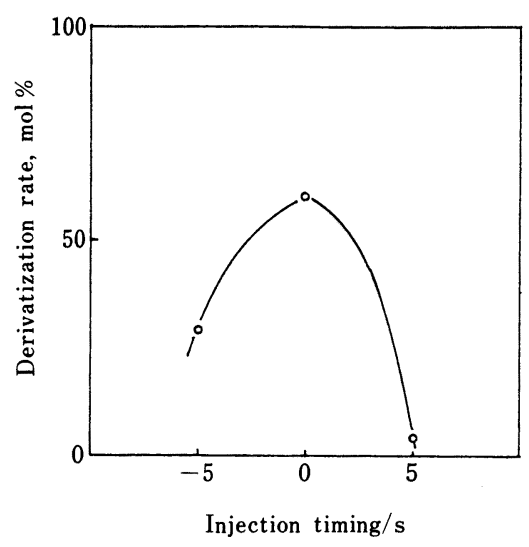

Fig. 4 Effect of the injection timing to the derivatization rate

-5 means that pyrolysis is carried out 5 second later than injection of the alkylating reagent. 0 means that pyrolysis is carried out just as reagent is injected. 
解される前に, 揮発又は分解して系内からカラムへ移行 していると考えられる.

そこで, 著者はこの誘導体化試薬か加熱されるタイミ ングをずらすために, Fig. 1 に示すような熱分解用プ ローブを使用した。このプローブでは, 装着されたセプ タムより，マイクロシリンジで誘導体化試薬を直接分解 炉内に導入でき，更に熱分解と誘導体化試薬の導入の夕 イミングを自由に変化させることができる.

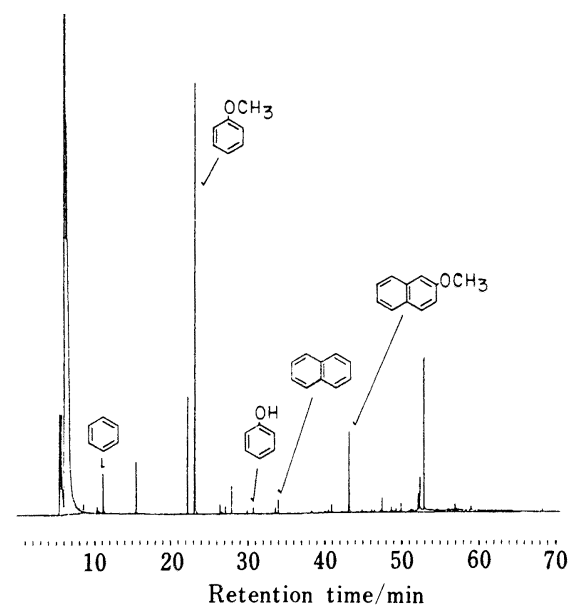

Fig. 5 Pyrogram of copolyester observed by the direct injection method

Sample weight: ca. $0.15 \mathrm{mg}$; Alkylating reagent: 3 $\mu l$. The derivatization rate was $97 \mathrm{~mol} \%$ for phenol.

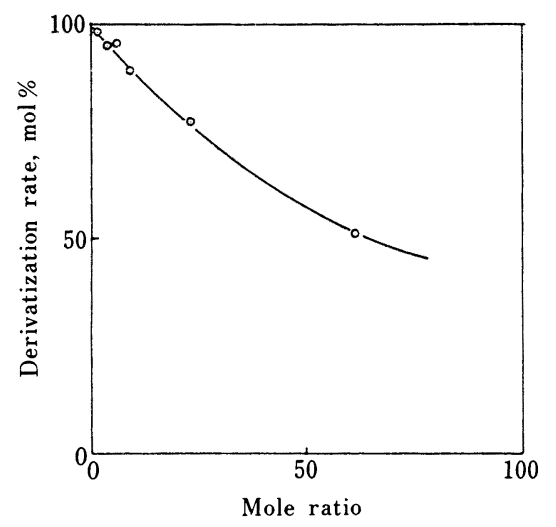

Fig. 6 Relationship between the ratio of alkylating reagent to sample and derivatization rate in the direct injection method

The mole ratio was varied by varing the sample weight at the constant reagent volume $(3 \mu \mathrm{l})$.
Fig. 4 に誘導体化試薬の注入のタイミングと誘導体化 率の関係を示した，最大の誘導体化率は，熱分解と同時 に誘導体化試薬を注入したときに得られている。しか し，この場合でも実際には Challinor 法と比較して，わ ずかに熱分解より遅れて誘導体化試薬が導人されている と考えられる.

Fig. 5 に，最大の誘導体化率が得られた，パイログラ ムを示したが，パイログラム上には未誘導体化合物，即 ちフェノールはほとんど検出されない。

Fig. 6 には，試薬量一定の場合の誘導体化試薬と試料 のモル比と誘導体化率の関係を示した。それより，モル 比 8 のとき, 最大 97 モル\%の誘導体化率が得られる ことが分かる。

Fig. 6 は，更に非常に興味ある現象を示している。 す なわち, 試料に対する誘導体化試薬のモル比が増加する に従って, 誘導体化率は減少している. Fig. 7 には, 試 料量一定で, 誘導体化試薬を変化させたときの, 誘導体 化率を示した。この場合は, 誘導体化試薬の増加に伴 い, 誘導体化率も増加している. そこで, 著者らは Fig. 6 に示される誘導体化率の減少は, 誘導体化試薬と試料 量のモル比の増加によるものではなく, 試料量の減少に よるものと推察した。すすおち, 試料量が少ない場合, 熱分解も早く，更に熱分解生成物も即座に力ラムに導入 されるため, 誘導体化試薬との混合，すなわち誘導体化 反応が不十分であり，その結果誘導体化率が低下すると 考えた。それに対し，試料量が多量の場合は，少量の場 合と比較して，熱分解装置内に分解生成物が存在する時 間も長く，十分な誘導体化反心が行われていると考え た.

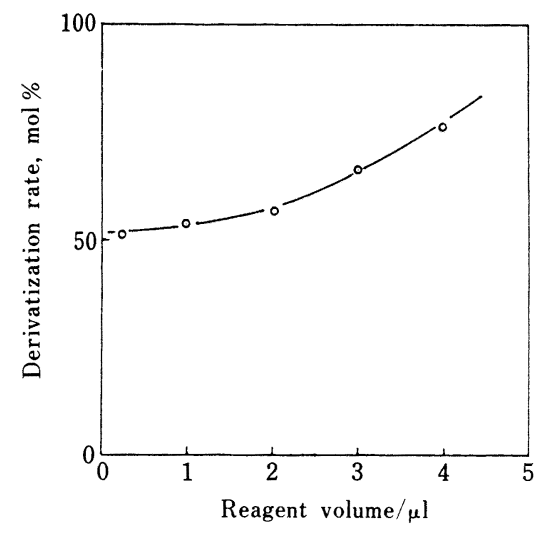

Fig. 7 Effect of volume of alkylating reagent to derivatization rate in the direct injection method Sample weight: $0.05 \mathrm{mg}$ 
3・4 Challinor 法における誘導体化反応の機構に関 する若干の考察

著者は，95 モル％以上という高い誘導体化率を得た にもかかわらず, 得られたパイログラム上には, p-メト キシ安息香酸メチル及び 2-メトキシ-6-ナフトエ酸メチ ルが検出されない, この原因は, Ohtani らの研究5)を

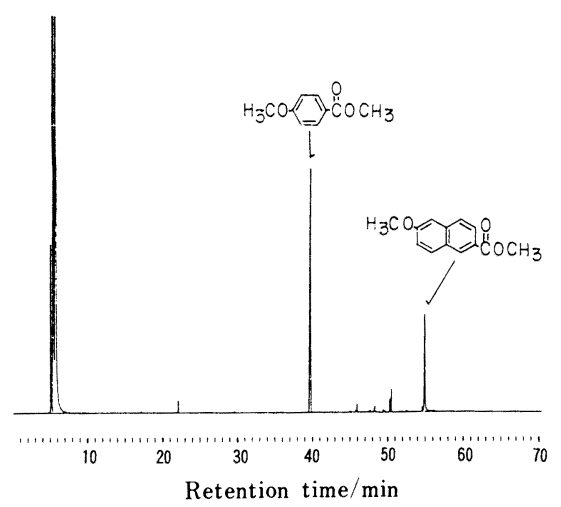

Fig. 8 Pyrogram of copolyester observed by Ohtani's method ${ }^{5)}$

Pyrolysis temperature: $358^{\circ} \mathrm{C}$; Sample weight: $c a$. $0.1 \mathrm{mg}$. Volume of tetramethylammonium hydroxide: $3 \mu \mathrm{l}$

a) Conventional method

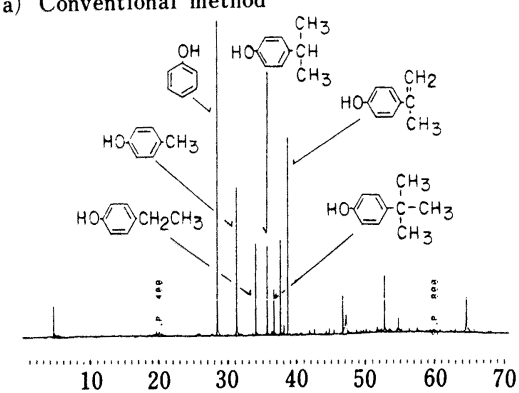

b) Direct injection method

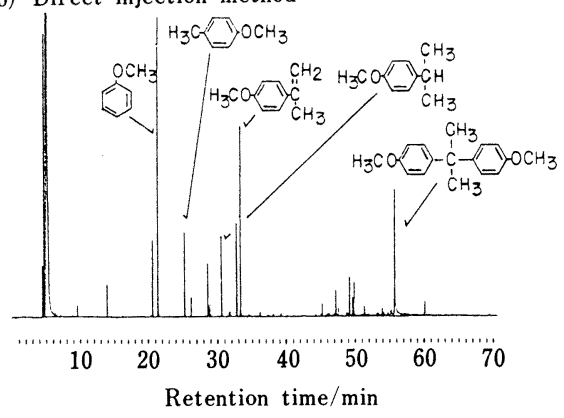

Fig. 9 Pyrograms of polycarbonate

Sample weight: $c a$. $0.1 \mathrm{mg}$; Pyrolysis temperature: $590^{\circ} \mathrm{C}$
用いて説明できる. Ohtani らが報告しているように， 同一のポリマーを用い，通常の Py-GC ではほとんど熱 分解を起こさない比較的低い温度で, 水酸化テトラメチ ルアンモニウムと反応させることより，Fig. 8 に示すよ うに主として $p$-メトキシ安息香酸メチル及び 2-メトキ シ-6-ナフトエ酸メチルのみが検出されている.この反 応系では, 熱分解というよりむしろ, エステル交換反応 が起こっていると考えられる.

Challinor 法においても, 同様の反忍が起こっている ことが予測できる。それに対して，直接導入法では，水 酸化テトラメチルアンモニウムは直接高分子試料と接す ることがないので，エステル交換反応は起こらず，熱分 解亡誘導体化反忘のみが起こっていると考えられる.こ の種の試料の熱分解では, 脱炭酸反応が優先して, 比較 的 $p$-ヒドロキシ安息香酸や 2-ヒドロキシ-6-ナフトエ酸 はフラグメントとして生成しにくく，その結果として直 接導入法では $p$-メトキシ安息香酸メチル及び 2-メトキ シ-6-ナフトエ酸メチルが検出されない.

\section{$3 \cdot 5$ 幾つかのポリマーの定性分析への応用}

Fig. 9 に, 誘導体化試薬を直接導入する本法を用いて

a) Conventional method

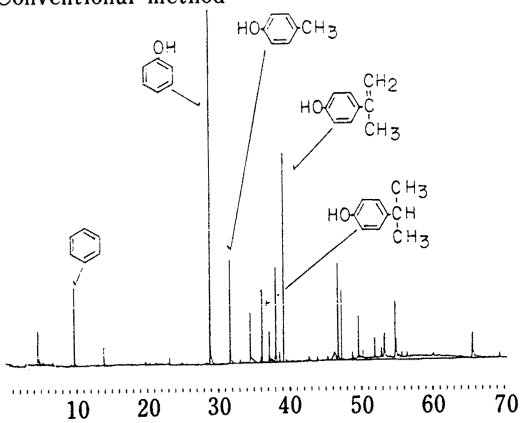

b) Direct injection method

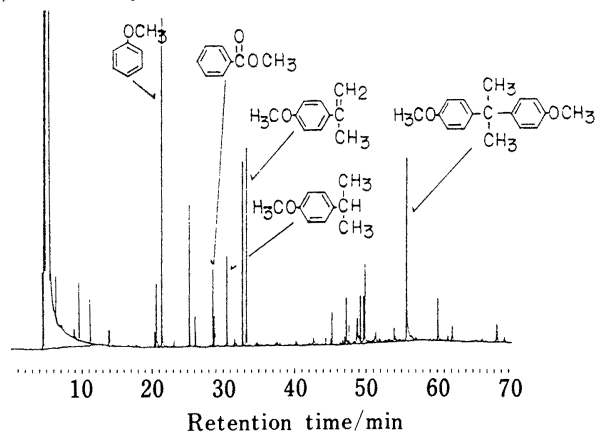

Fig. 10 Pyrograms of polyarylate

Sample weight: ca. $0.1 \mathrm{mg}$; Pyrolysis temperature: $590^{\circ} \mathrm{C}$ 


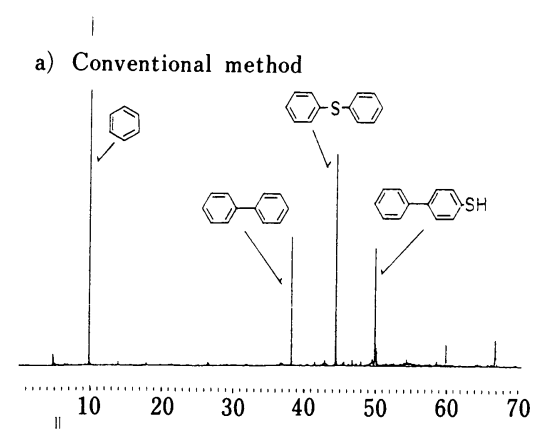

b) Direct injection method

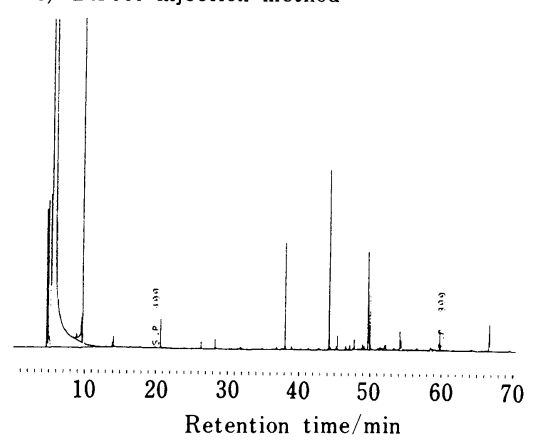

Fig. 11 Pyrograms of poly(phenylene sulfide) Sample weight: ca. $0.1 \mathrm{mg}$; Pyrolysis temperature: $764^{\circ} \mathrm{C}$
測定したポリカーボネートのパイログラムを示した。幾 つかのフェノール化合物のメチル誘導体化物の他に，ビ スフェノール-Aのメチル誘導体も検出される． Fig. 10 にはポリアリレートについての測定結果を示した。幾つ かのフェノール類及びビスフェノールーA のメチル誘導 体化物の他に，安息香酸メチルも検出されている。一 方, ビちらの場合もフェノール類は，ほとんど検出され ないことより，誘導体化がほぼ完全であることが分か る. Fig. 11 にはポリフェニレンスルフィドへの伈用例 を示した。この場合は，主要なピークは通常の $\mathrm{Py}-\mathrm{GC}$ の場合とほとんど同一であり，フェノールとチオールが ほぼ類似した性質を持つにもかかわらず，水酸化テトラ メチルアンモニウムはチオール類を誘導体化しないこと が分かる．このことは，熱分解生成物の夕イプに忘じ て, 誘導体化試薬を選択する必要性を暗示している.

\section{文献}

1) 柘植 新: 分析化学, 35, 417 (1986).

2) L. D. Metcalfe, C. N. Wang: J. Chromatogr. Sci., 19, $530(1981)$.

3) J. F. Klebe, H. Finkbeiner: J. Am. Chem. Soc., 88, 3390 (1966).

4) J. M. Challinor: J. Anal. Appl. Pyrolysis, 16, 323 (1989), 18, 233 (1991).

5) H. Ohtani, R. Fujii, S. Tsuge: J. High Resolut. Chromatogr., 14, 388 (1991).

is

Investigation of the derivatization method for the identification of copolyester by the pyrolysis-GC. Sadayuki Saтон (Polymer Research Laboratory, Idemitsu Petrochemical Co., Ltd., 1-1, Anesaki-kaigan, Ichihara-shi, Chiba 299-01)

Pyrolysis-derivatization-gas chromatography developed by J. M. Challinor was applied for the identification of copolyester formed from $p$-hydroxy benzoic acid and 2-hydroxy-6naphthoic acid. By the proposed method of adding the alkylating reagent (tetramethyl ammonium hydroxide) to the polymer sample before pyrolysis, the derivatization efficiency was not high enough. Therefore, some modifications were made to attain optimum conditions. The quantitative derivatization of the pyrolysis products was able to get by introducing the reagent into the pyrolyzer during the pyrolysis. This modified method was applied to identify various synthetic polymers. The derivatization mechanism during pyrolysis was also discussed.

(Received September 21, 1991)

\section{Keyword phrases}

pyrolysis-derivatization-GC; identification of copolyester; direct injection of alkylating reagent; derivatization mechanism. 